\title{
PROTON AND ION MICROBEAM COLLIMATION FOR IRRADIATION OF BIOLOGICAL SAMPLES IN AIR
}

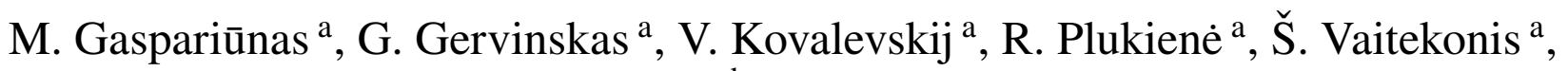 \\ V. Levenets $\mathrm{b}$, and A. Plukis \\ a Institute of Physics, Center for Physical Sciences and Technology, Savanoriu 231, LT-02300 Vilnius, Lithuania \\ E-mail: rita@ar.fi.lt \\ ${ }^{\mathrm{b}}$ National Science Center Kharkov Institute of Physics \& Technology, Akademicheskaya 1, 61108 Kharkov, Ukraine
}

Received 19 March 2010; revised 23 August 2010; accepted 16 September 2010

\begin{abstract}
The single cell irradiation using the tandem-type proton/ion accelerator is previewed for microdosimetry purposes in the biological media (yeast cells). Individual cells can also be targeted within a population to obtain the new in vivo data concerning a bystander effect. Usually the strong focusing systems are used for compression of the beam to $\mu$ m diameter. In this work we assess the possibility to apply a simple mechanical collimator. The detailed modelling with MCNPX v.2.6 and GEANT4 v.9.1 codes shows that the 1.4-1.8 MeV proton beam energy deposition can be distributed in the $100 \mu \mathrm{m}$ cell layer with a narrow collimator. An additional focusing system is needed for single cell irradiation. The method for calculation of the microbeam proton doses deposited in separate cells is prepared for the dose rate prediction in the 1.0-2.5 MeV proton and 3.5-3.7 MeV $\mathrm{He}^{2+}$ ion energy range. The experimental proton beam measurements are performed and compared with modelling data.
\end{abstract}

Keywords: single cell irradiation, external ion beam, MCNPX, GEANT4 modelling

PACS: 41.75.-i, 02.70.Uu, 87.53.Bn

\section{Introduction}

Micro-irradiation technique is being used to study the ionizing radiation interaction processes in the cells. One of such phenomena is the bystander effect, where unirradiated cells are damaged through signaling pathways initiated by a nearby irradiated cell. The fact that they are observed at low doses has suggested that they may be important in carcinogenesis and radiation risk and may call into question the linear non-threshold model currently used for extrapolating risk from high doses to low doses [1]. Further research is required to confirm or deny whether this may be the case. Recently bystander effects have been detected in the unicellular eukaryote, the fission yeast Schizosaccharomyces pombe [2].

One of the applications of the tandem ion accelerator "Tandetron 4110A" is the mutant Saccharomyces cerevisiae yeast strain cell irradiation [3] for microdosimetry and bystander effect in yeast population experiments. The yeast cell immobilized on the selfassembled monolayer further can be exposed to charged particles targeted to regions (patterned arrays) of individual cells to look for mechanisms of response.

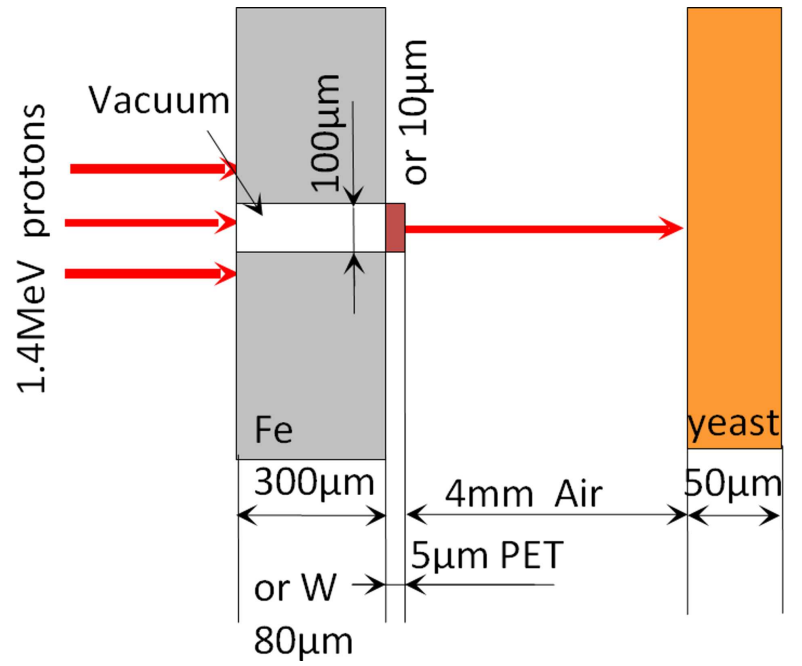

Fig. 1. Simplified sketch of biological sample (yeast) irradiation with a $1.4 \mathrm{MeV}$ proton beam and two collimators: $300 \mu \mathrm{m}$ thick iron foil with a $100 \mu \mathrm{m}$ diameter pinhole or $80 \mu \mathrm{m}$ thick tungsten foil with a $10 \mu \mathrm{m}$ diameter pinhole.

Depending on the initial ion type, in the tandem ion accelerator the maximal achievable energy for $\mathrm{H}^{+}$is 2.5 MeV, for $\mathrm{He}^{2+} 3.75 \mathrm{MeV}$, and for heavy ions $(\mathrm{C}$, $\mathrm{Fe}, \mathrm{Sn}$, etc.) triple charged $\left(\mathrm{Z}^{3+}\right) 5.0 \mathrm{MeV}$, quadruple charged $\left(\mathrm{Z}^{4+}\right) 6.25 \mathrm{MeV}$. It is possible to focus 


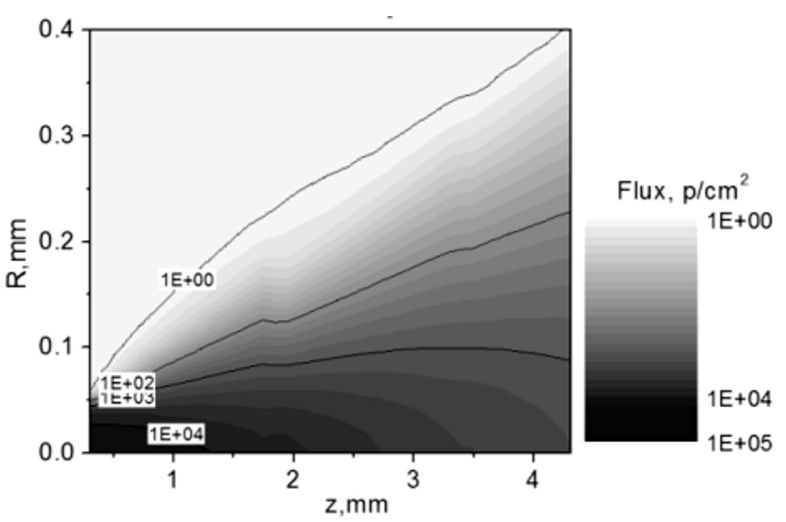

Fig. 2. 1.4 MeV proton beam spread and intensity reduction in the air gap in front of a biological sample in the case of the Fe collimator with the $100 \mu \mathrm{m}$ diameter pinhole. Flux is normalized per one incident proton.

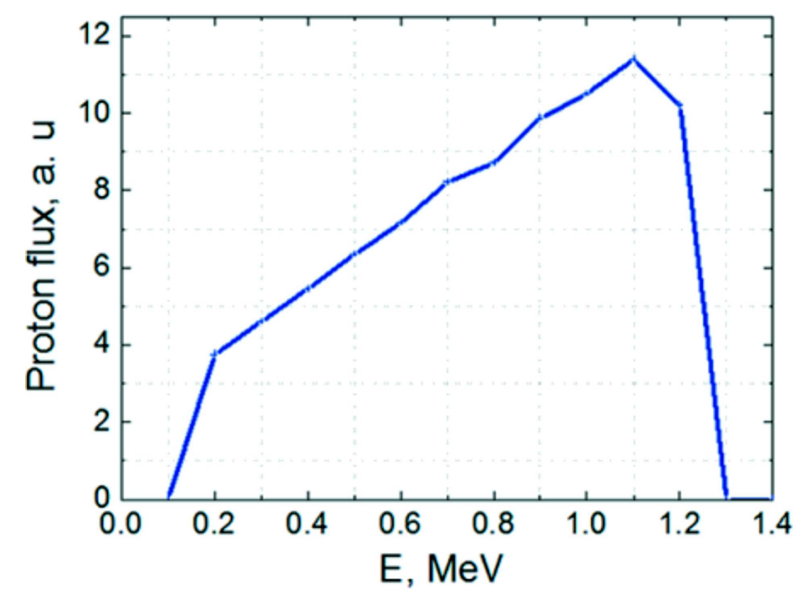

Fig. 3. 1.4 MeV proton energy distribution in the cell layer.

the ion beam into the $4 \mathrm{~mm}$ diameter spot of $10 \mathrm{pA}-$ $100 \mathrm{nA}$ beam current. The modelling of the $1.4 \mathrm{MeV}$ energy proton beam optimization for the cell layer irradiation is performed. The method for calculation of the microbeam proton doses deposited in separate cells is proposed for the dose rate prediction in the 1.0-2.5 MeV proton and 3.5-3.7 $\mathrm{MeV} \mathrm{He}^{2+}$ ion energy range. The proton energy distribution and radiation dose are modelled using the MCNPX v.2.6 [4] and GEANT4 v.9.1 [5] code packages. Experimental proton beam measurements were performed using the tandem ion accelerator "Tandetron 4110A" with the Si detector, and the calibration curve according to modelling data was obtained.

\section{Proton beam for cell layer irradiation}

A simplified sketch of the yeast cell monolayer irradiation with the proton beam in air is presented in Fig. 1 . The proton beam reaches a biological target through the collimator $(100 \mu \mathrm{m}$ diameter pinhole in the case of a $300 \mu \mathrm{m}$ thick iron (Fe) collimator and $10 \mu \mathrm{m}$ diameter pinhole in the case of a $80 \mu \mathrm{m}$ thick tungsten (W) collimator) and the $5 \mu \mathrm{m}$ thick polyethyleneterephthalate (PET) film window preserving the vacuum chamber from atmospheric pressure. The air gap between the PET window and the biological sample $\left(\mathrm{H}_{2} \mathrm{O}\right.$ in GEANT model case) is supposed to be as small as possible: $4 \mathrm{~mm}$ in this case because of the proton energy loss along their path in air. The default minimal tracking energy for protons in MCNPX is $1 \mathrm{MeV}$. It was reduced to $0.01 \mathrm{MeV}$ for present calculations to include the lower energy proton transport. The secondary electrons and photons are not tracked but implicitly included in the total energy deposition of protons. Due to the low energy of protons and ions only atomic interaction processes have been taken into account and nuclear interaction libraries were not included in MCNPX calculations. This approach has been checked with GEANT4 where the low energy electromagnetic interaction process library was used, and secondary particles (electrons and photons) were tracked explicitly. The calculated proton beam spread and intensity reduction in the air gap in front of the biological sample are presented in Fig. 2. The $1.4 \mathrm{MeV}$ proton flux intensity is reduced by three orders of magnitude starting with the backward surface of the PET window. The $1.4 \mathrm{MeV}$ proton energy distribution in the cell layer is presented in Fig. 3. The largest part of protons are in the 0.9$1.0 \mathrm{MeV}$ energy range and this remains sufficient for penetration through the yeast cell and the surrounding water film.

The energy deposition modelled with MCNPX for different collimators and the proton flux modelled with GEANT (for a wide collimator) in the yeast cell layer are presented in Figs. 4(a-d) and 5. The maximum of deposited energy is up to $27 \mu \mathrm{m}$ in the sample depth and further the deposited energy decreases (see Fig. 4(a, c) for different collimators). It means that protons cross the cell layer almost with the same intensity. The energy deposition on the first cell surface perpendicular to proton beam is presented in Fig. 4(b, d) for $100 \mu \mathrm{m}$ and $10 \mu \mathrm{m}$ diameter pinholes for different collimators, respectively. The highest energy deposition occurs in the $100 \mu \mathrm{m}$ diameter region. It is interesting to note that the beam spread is almost the same for the narrow collimator as for a wide one. It is caused by the beam scatter in the PET window and in the air gap, and the collimator pinhole does not determine the beam profile after $4 \mathrm{~mm}$ air gap. One must note that the proton energy deposition probability presented in Fig. 4(a-d) is normalized 

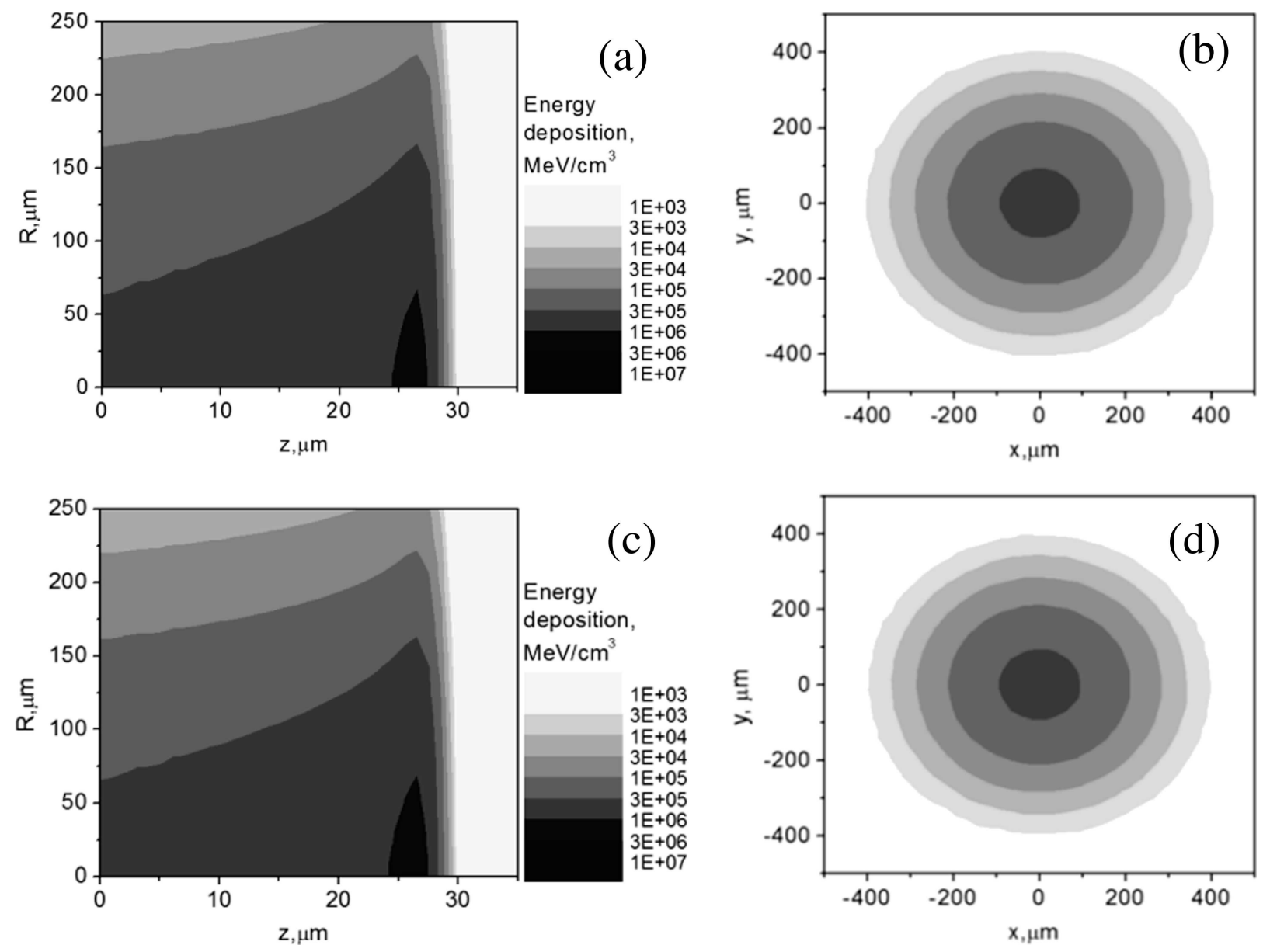

Fig. 4. 1.4 MeV proton beam energy deposition in the cell layer calculated using MCNPX code: (a) energy deposition along the $35 \mu \mathrm{m}$ cell layer; (b) energy deposition on the first cell layer surface perpendicular to the proton beam in the case of the Fe collimator with the $100 \mu \mathrm{m}$ diameter pinhole; (c, d) the same as (a) and (b), respectively, in the case of the $\mathrm{W}$ collimator with the $10 \mu \mathrm{m}$ diameter pinhole.

per incident proton. It is worthwhile mentioning that at the same accelerator beam current the power deposition will be two orders of magnitude higher for the wide collimator.

The similar result was obtained with GEANT modelling of the $1.4 \mathrm{MeV}$ proton beam interaction with the $\mathrm{H}_{2} \mathrm{O}$ layer. Proton flux on the first $\mathrm{H}_{2} \mathrm{O}$ layer surface perpendicular to the proton beam is presented in Fig. 5. The most intensive protons fall in $\sim 200 \mu \mathrm{m}$ spot in the cell layer region.

As the beam spread at the distance of a few $\mathrm{mm}$ exceeds $100 \mu \mathrm{m}$, for the single cell or selective irradiation of cell parts one needs either to use a different or additional collimation system or to ensure the cell separation before exposure to the beam.

\section{Experimental measurement of the external proton beam properties}

The experimental set-up presented in Fig. 1 was assembled for the Tandetron 4110A accelerator in the
Center for Physical Sciences and Technology (Vilnius). The pinholes in collimators have been made by laser

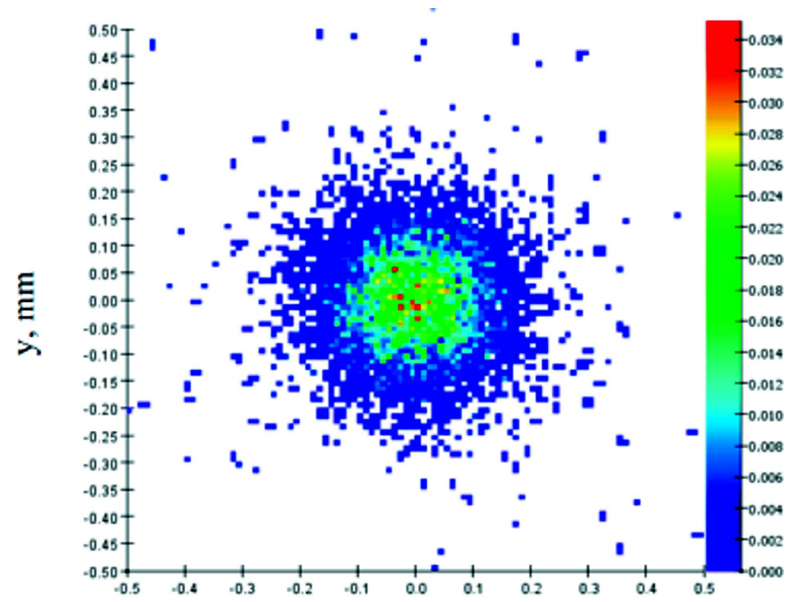

$\mathrm{x}, \mathrm{mm}$

Fig. 5. GEANT modelling of the $1.4 \mathrm{MeV}$ proton flux in the $\mathrm{H}_{2} \mathrm{O}$ layer: proton flux on the first $\mathrm{H}_{2} \mathrm{O}$ layer surface perpendicular to the proton beam. 


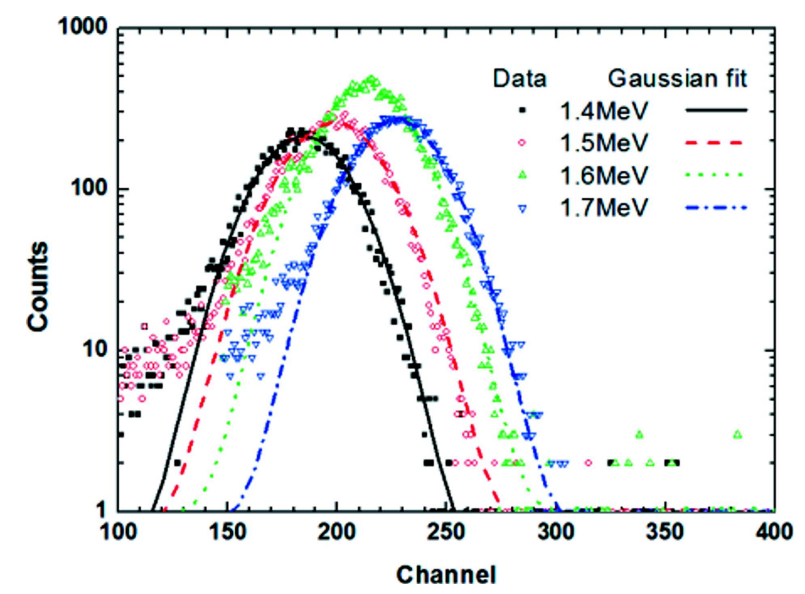

Fig. 6. Energy spectra of protons in atmosphere measured with the Si detector (points) together with Gaussian fits (curves).

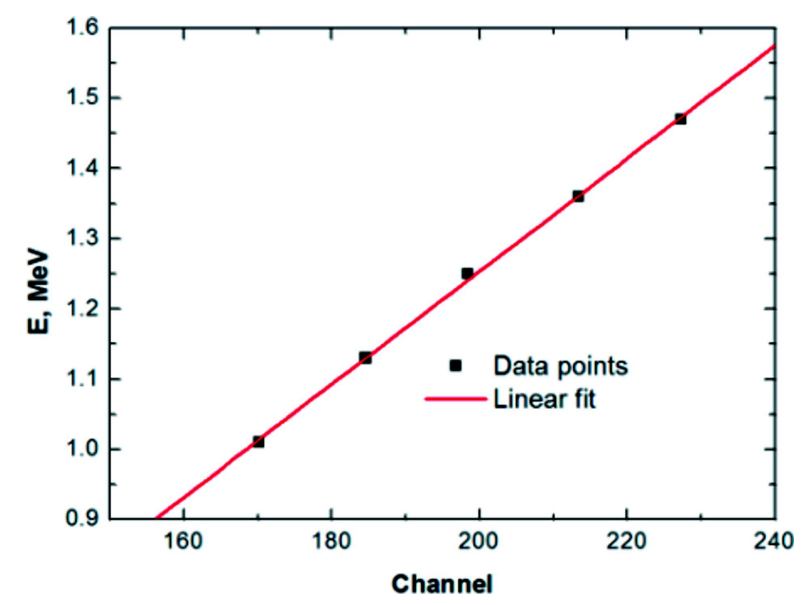

Fig. 7. Energy calibration curve of the Si detector (see text for details).

drilling: the $100 \mu \mathrm{m}$ diameter pinhole in a stainless steel foil and the $10 \mu \mathrm{m}$ diameter pinhole in the tungsten foil. Tungsten was found to be a more suitable material for the narrow pinhole formation due its hardness and higher melting temperature. The dimensions of the collimator holes were checked by the optical microscope. Protons were registered with the DKPsd-125 type Si detector with the surface area of $125 \mathrm{~mm}^{2}$, the depletion layer of $188 \mu \mathrm{m}$ thickness, and the given energy resolution of $70 \mathrm{keV}$. The multichannel analyzer (MCA) DSA-1000 (Canberra) was used for spectral analysis. Proton spectra for some beam energies are presented in Fig. 6. It is necessary to point out that the poor energy resolution FWHM $>200 \mathrm{keV}$ is caused by the high electronic noise level due to the measurements in air.

In order to calibrate the energy spectrum of the semiconductor detector, the energy peaks were fitted by a Gaussian profile and the peak centres were found. The peak centres were assigned to calculated beam energies at the detector, because one must take into account the proton energy loss in the beam window and in the air gap between the window and the detector. The results are presented in Fig. 7. One can note a good energy scale linearity validating MCNPX modelling of the proton beam interaction and energy losses outside the vacuum chamber.

Despite the possibility of registration of protons in the $100 \mu \mathrm{m}$ diameter beam, it was not possible to obtain quantitative measurements of the proton beam intensity and relate them to the beam current in the vacuum chamber under our measurement conditions. The main problem was the long dead time of the detector and MCA limited to proton beam intensities up to $10^{5} \mathrm{~s}^{-1}$ (corresponding external beam current was a few tens of fA).

The narrow pinhole ( $10 \mu \mathrm{m}$ diameter) collimator was used for the quantitative beam intensity measurements. The experimental results are presented in Table 1. Due to proton beam current and terminal voltage fluctuations, it was difficult to measure the focused beam current value. In order to obtain a homogeneous and steady beam, it was defocused to $10-12 \mathrm{~cm}^{2}$ area. We estimate the beam current density measurement uncertainty as $30 \%$ of its value from current measurements using the Faraday cylinder. The external proton beam intensities calculated from the measured proton beam current density in the vacuum chamber, taking into account modelled transfer efficiency by collimator, are presented for comparison. As seen in Table 1, there is a reasonably good agreement between the calculated and measured external proton beam intensities.

\section{Simulation of an additional collimation system for single cell irradiation}

As an additional collimator, the tantalum (Ta) disc of $40 \mu \mathrm{m}$ thickness with a $2 \mu \mathrm{m}$ pinhole was simulated in front of the PET window. The 1.0-2.5 MeV proton and 3.5-3.7 $\mathrm{MeV} \mathrm{He}^{2+}$ ion beam irradiation of the cell monolayer was evaluated within the micrometre precision. The cross-sectional view of energy deposition in the cell monolayer irradiated with $2.5 \mathrm{MeV}$ proton and $3.7 \mathrm{MeV} \mathrm{He}^{2+}$ ion beam is presented in Fig. 8. One can observe that in the case of proton irradiation the maximal deposited energy is distributed in the $10 \mu \mathrm{m}$ region, which corresponds to the yeast cell size. $\mathrm{He}^{2+}$ ion irradiation is more dispersed as compared with protons. Distinct from the proton irradiation case, the $3.7 \mathrm{MeV} \mathrm{He}^{2+}$ ions Bragg peak is at the 6th $\mu \mathrm{m}$ of the cell monolayer (yeast cell nucleus region) and therefore the possibility of different cell part irradiation 

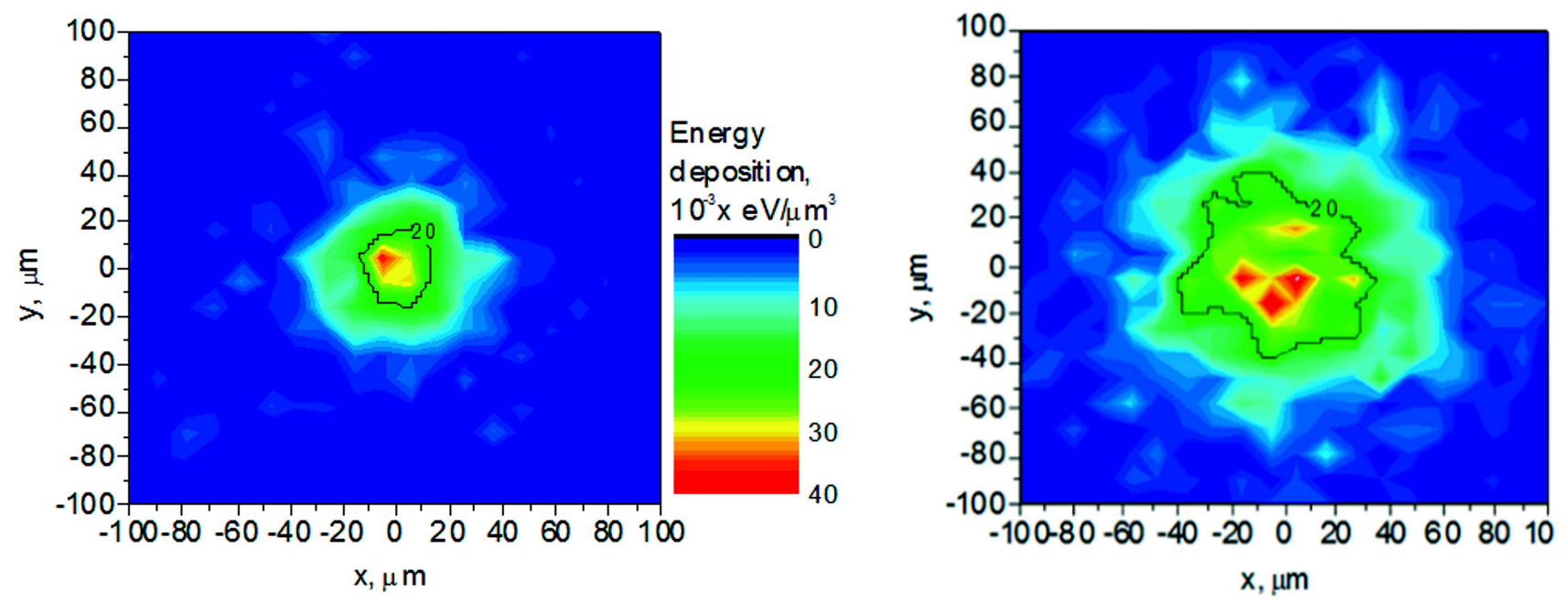

Fig. 8. Simulation of the (a) $2.5 \mathrm{MeV}$ proton and (b) $3.7 \mathrm{MeV} \mathrm{He}^{2+}$ ion beam energy deposition on the cell monolayer surface using an additional collimator.

Table 1 . The external proton beam parameters.

\begin{tabular}{cccc}
\hline $\begin{array}{c}\text { Proton energy, } \\
\mathrm{MeV}\end{array}$ & $\begin{array}{c}\text { Proton beam current } \\
\text { density, } \mathrm{pA} \mathrm{cm}^{-2}\end{array}$ & $\begin{array}{c}\text { Calculated proton beam } \\
\text { intensity, } \mathrm{s}^{-1}\end{array}$ & $\begin{array}{c}\text { Experimental proton beam } \\
\text { intensity, } \mathrm{s}^{-1}\end{array}$ \\
\hline 1.8 & $100 \pm 30$ & $490 \pm 150$ & $510 \pm 20$ \\
1.9 & $100 \pm 30$ & $490 \pm 150$ & $550 \pm 20$ \\
2.0 & $90 \pm 30$ & $440 \pm 150$ & $410 \pm 20$ \\
\hline
\end{tabular}

Table 2. The proton/ion microbeam parameters and calculation results of dose deposition in the yeast cell.

\begin{tabular}{cccc}
\hline & $I, \mathrm{pA}$ (for single particle per cell) & Energy deposition, $\mathrm{MeV} /\left(\mathrm{g} \mathrm{s}^{-1}\right.$ ) & Dose rate, $\mathrm{mGy} / \mathrm{s}$ \\
\hline Proton energy, $\mathrm{MeV}$ & & & \\
2.5 & 65 & $2.44 \mathrm{E}+08$ & 39.1 \\
2.0 & 116 & $2.88 \mathrm{E}+08$ & 46.1 \\
1.0 & 888 & $4.23 \mathrm{E}+08$ & 67.8 \\
\hline $\mathrm{He}^{2+}$ ion energy, $\mathrm{MeV}$ & & & 236.6 \\
3.7 & 531 & $1.48 \mathrm{E}+09$ & 192.5 \\
\hline
\end{tabular}

becomes feasible by changing the ion energy and/or the collimator pinhole position.

In reality the above modelled proton beam collimation is complicated because of difficulties in manufacturing a pinhole of $2 \mu \mathrm{m}$ diameter with right edges and aligning along the incident beam line.

\section{Microbeam proton/ion dose prediction for yeast cells}

Single cell irradiation with the exact number of charged particles down to one particle per cell can be achieved using the accelerator-based microbeam technique. The calculation of the microbeam proton doses deposited in the yeast cells is performed in the 1.0-
2.5 $\mathrm{MeV}$ proton and 3.5-3.7 $\mathrm{MeV} \mathrm{He}^{2+}$ ion energy range. The calculation results are presented in Table 2 .

In the second column of Table 2 , the proton/ion microbeam parameters are defined in order to obtain one particle per yeast cell. The deposited dose rate was recalculated from the proton/ion energy deposition in $\mathrm{MeV} / \mathrm{g}$ (units used in MCNPX code) for the corresponding beam current. We should note that the obtained beam current (hundreds of pA) is exactly in the optimal current range for the Tandem type ion accelerator "Tandetron 4110A".

\section{Conclusions}

Single cell irradiation with the exact number of charged particles down to one particle per cell can be 
achieved using the accelerator-based microbeam technique. We show that one can use a simple mechanical collimator without the precise focusing system to obtain external beams of the order of $100 \mu \mathrm{m}$ in diameter. For the single cell or selective cell part irradiation one needs either to use a different or additional collimation system or to ensure that the cells are separated before the beam exposure. The calculation of the microbeam proton dose rates deposited in the yeast cells is performed in the 1.0-2.5 MeV proton and 3.5-3.7 $\mathrm{MeV} \mathrm{He}^{2+}$ ion energy range using the additional collimator.

\section{Acknowledgements}

This research was supported by the Lithuanian State Science and Studies Foundation (No. V-30/2009/V09045) and Research Council of Lithuania (Nos. TAP31/2010 and TAP-59/2010) within the frame of bilateral Lithuanian-Ukrainian research and development collaboration project.

\section{References}

[1] M. Folkard, K.M. Prise, G. Grime, K. Kirkby, and B. Voinovic, The use of microbeams to investigate radiation damage in living cells, Appl. Radiat. Isot. 67, 436-439 (2009).

[2] L.C. DeVeaux, L.S. Durtschi, J.G. Case, and D.P. Wells, Bystander effects in unicellular organisms, Mutat. Res. Fund. Mol. Mech. Mutagen. 597(1-2), 78-86 (2006).

[3] B. Remeikytè, R. Plukiené, D. Čitavičius, V. Remeikis, and Š. Vaitekonis, Yeast Saccharomyces cerevisiae response to UV and Gamma Irradiation, Environ. Chem. Phys. 26(4), 148-156 (2004).

[4] D.B. Pelowitz, MCNPX User's Manual, Version 2.6.0, Report LA-CP-07-1473 (Los Alamos National Laboratory, New Mexico, 2008), https://mcnpx.lanl.gov/.

[5] S. Agostinelli, J. Allison, K. Amako, J. Apostolakis, H. Arauio, P. Arce, M. Asai, D. Axen, S. Baneriee, G. Barrand, et al., GEANT4 - a simulation toolkit, Nucl. Instrum. Methods A 506, 250-303 (2003).

\title{
PROTONŲ IR JONŲ MIKROPLUOŠTELIO KOLIMAVIMAS BIOLOGINIŲ BANDINIŲ APŠVITAI ORE
}

\author{
M. Gaspariūnas ${ }^{\text {a }}$, G. Gervinskas ${ }^{\text {a }}$, V. Kovalevskij ${ }^{a}$, R. Plukiené ${ }^{a}, \check{S}$. Vaitekonis ${ }^{a}$, V. Levenets ${ }^{\text {b }}$, A. Plukis ${ }^{\text {a }}$ \\ a Fizikos institutas, Fiziniu ir technologijos mokslu centras, Vilnius, Lietuva \\ ${ }^{\mathrm{b}}$ Nacionalinis mokslo centras Charkovo Fizikos ir technologijos institutas, Charkovas, Ukraina
}

\begin{abstract}
Santrauka
Jonizuojančiosios spinduliuotès poveikio gyviems mikroorganizmams (mielèms) tyrimai, naudojant greitintuvais kuriamus jonu pluoštelius, i̇manomi švitinant protonu pluošteliu ore - gyvybei palankioje terpèje. Paprastai naudojamos stipraus fokusavimo sistemos suspaudžia pluoštelį iki kelių mikrometrų dydžio. Šiame darbe tiriamos alternatyvios mechaninio pluoštelio kolimavimo galimybès.
\end{abstract}

Modeliavimas MCNPX ir GEANT programomis parodè, kad
$1,4-1,8 \mathrm{MeV}$ protonų pluoštelis gali būti paskirstytas $100 \mu \mathrm{m}$ ląstelių sluoksnyje, o atskirų ląstelių apšvitinimui reikalinga papildoma kolimavimo sistema. Atliktas $1,0-2,5 \mathrm{MeV}$ protonų ir 3,5-3,7 MeV jonų mikropluoštelio apšvitos dozių mielių ląstelèms modeliavimas su papildomu kolimatoriumi.

Sukurtas protonu pluoštelio, gauto greitintuvu Tandetron 4110A, išvadas iš vakuumo ị orą ir atlikti eksperimentiniai jo savybių matavimai. Duomenys palyginti su modeliavimo rezultatais. 